ISSN 1991- 8690

Website: http://jsci.utq.edu.iq
الترقيم الاولي • 199 - 199

Email: utjsci@utq.edu.iq

\title{
Theoretical Semi-Empirical Calculation of Molecular Structure of Schiff Base Complexes Zn (II).
}

\author{
Adil Muala \\ kawkab Ali \\ Department of Chemistry - College of Education - University of Basrah.
}

\begin{abstract}
$\underline{\text { Abstract }}$
Zn-Schiff-base Complexes(II) have been synthesized. The Schiff-bases prepared and their complexes were identified by IR, UV-Visible and elemental analysis (CHN). These experiments show that transition metal can form complexes with Schiff base in the ratio 1:2[M:L]. The Schiff-base(I,II) and their complexes(III,IV) were studied by quantum chemical methods, the optimized structures of the compounds(I,II,III,IV) were obtained by the semi-empirical PM3 method. The value of total energy for complexes as found (III,IV) is less than Schiff base ligand (I,II), which strongly indicates the stability of the complexes. Also the dipole moment of complexes high values as compared with Schiff base ligand. The changes of the bond lengths in complex (IV) indicate the presence of $\pi$-conjugation in the aromatic system for aromatic ligand (II) if compared with aliphatic ligand(I). The mean distances $\mathrm{N}-\mathrm{Zn}$ and $\mathrm{O}-\mathrm{Zn}$ in the complex(IV) an decreased compared with the complex (III))because of the complex (IV) have high electrostatic attraction.
\end{abstract}

Keyword: Schiff-base, Transition metal complexes, Semiempirical PM3.

$$
\begin{aligned}
& \text { المستخلص } \\
& \text { تم تحضيرالليكاندات قواعد شف ومعقدات الزنك الجديدة. . قواعد شف ومعقداتها المحضرة شخصت باستخدام مطيافية } \\
& \text { الاشعة تحت الحمراء والاشـعة المرئيـة وفوق البنفسجية وتحاليل العناصـر الدقيقة .وهدة التقنيات أستخدمت كوسيلة لتبيين } \\
& \text { التركيب الكيميائي للنتاسق. التقنيات بيينت ان الفلز الانتقالي يكون معقدات مـع القاعدة شف بنسبة (ب:1)(فلز - ليكاند). } \\
& \text { الحسـابات النظريـة لقواعد شف ومعقداتها قد درست بواسطة كيمياء الكم لأول مـرة ـ موائمسة التراكيب انجزت بطريقة الثبه } \\
& \text { تجريبية المستوى الثالثPM3 . الدراسة اظهرت أن الطاقة الكلية للمعقدات أقل(أكثر استقرار) من الطاقة الكلية لليكاندات قواعد } \\
& \text { شف, كدللك اظهرت الدراسة القيمة العالية لعزم ثنائي القطب للمعقدات مقارنة مع الليكانداتها, وكما بينت الحسابات ان تغيرات } \\
& \text { في أطوال الاواصر سببها نظام باي في النظام الاورماتي لليكاند الاورماتي مقارنة مع الليكاندالاليفاتي, كما اوضحت الدراسة } \\
& \text { ان طول الاصرة N-Zn و N-Zn في المعقد (IV) اقصر من نظيرتها في المعقد (III) بسبب التجادب الا لكتروستاتك } \\
& \text { العالي في المعقد (IV). }
\end{aligned}
$$




\section{Introduction}

Schiff base derived from an amine and aldehyde are important class of ligands that coordinate to metal ions via azomethine nitrogen and have been studied extensively $^{(1)}$. Schiff base complex are important for designing metal complex related to synthetic and natural oxygen carriers $^{(2)}$. The complexes

make these compounds effective and stereospecific catalysts for oxidation, reduction and hydrolysis and they show biological activity, and other transformations of organic

and inorganic chemistry' It is well know that some drugs have higher activity when administered as metal complexes than as freeligands ${ }^{(3,4,5) \text {. }}$

Computational chemistry is a new discipline, its advent and popularity have paralleled improvements in computing power during the last several decades, as with other disciplines, computational chemistry uses tools to understand chemical reactions and processes. Scientists use computer software to gain insight into chemical processes ${ }^{(6,7)}$. The challenges for computational chemistry are to characterize and predict the structure and stability of chemical systems, to estimate energy differences between different states, and to explain reaction pathways and mechanisms at the atomic level and bond geometries, angles, torsion, atomic charges $^{(8,9)}$. One of software tools for computational chemistry is HyperChem computational chemistry program,HyperChem is a versatile molecular modeler and editor and a powerful computational package. It offers many types of molecular and quantum mechanical calculations $^{(10-11)}$

In the present study, Zn-complexes of Schiff base were prepared, characterized by IR, UV-visible and elemental analyses and we have investigated the structural properties and relative stabilities for the first time theoretically by performing semiempirical PM3 calculation.

\section{Experimental}

\section{A - Chemicals}

Ethanol, methanol, salicylaldehyde, 1amino propane from ( Fluka Co), acetic acid, ether,aniline, chloroform, metal chloride (Merck Co), were purified before using $^{(12)}$

\section{B - Instruments}

IR- Infrared spectrophotometer from made by Buck Scientific Model 500 in the range $(4000-600) \mathrm{cm}^{-1}$. U.V-Visible spectrophometer, Model-U-1500- HITACH Melting Point, Model - Electro thermal melting point 9300 . The $\mathrm{CHN}$ analyses were carried out in Micro Analytical Center/ Faculty of Science, Cairo University/ Egypt

\section{Method}

\section{Synthesis of the Ligand ( I ) ${ }^{(13)}$}

$0.04 \mathrm{~mol}(3.20 \mathrm{ml})$ of the propyl amine and $0.04 \mathrm{~mol}(4.20 \mathrm{ml})$ salicylaldehyde were dissolved in $100 \mathrm{ml}$ absolute ethanol with a few drops of acetic acid as a catalyst. The solution was then refluxed for $2 \mathrm{~h}$. the ligand was obtained as yellow micro crystals, and washed with $20 \mathrm{ml}$ of cold absolute ethanol and then recrystallized for several times from ethanol - chloroform (1:3,v/v) $91 \%$ yield, m.p.102-103 ${ }^{0} \mathrm{C}$. Schiff bases have been characterized by elemental analysis and IR, UVspectra ,Figure1.

\section{Synthesis of Ligand (II) ${ }^{(14)}$}

The methanolic solution $50 \mathrm{ml}$ of aniline $3.65 \mathrm{ml}(0.04 \mathrm{~mol}) \quad$ with the methanolic solution $50 \mathrm{ml}$ of salciylaldehyde $4.20 \mathrm{ml}$ ( 0.04 mole) in equimolar ratio with a few drops of acetic acid as a catalyst. The mixture was refluxed with stirring for $3 \mathrm{~h}$, the condensation product was filtered, 
washed from ethanol, recrystalised with ethanol, and dried under reduced pressure over anhydrous $\mathrm{CaCl} 2(10)$. The resulting red product, $89 \%$ yield , m.p. 53-54 ${ }^{0} \mathrm{C}$. The
Schiff bases have been characterize by elemental analysis and IR, UV spectra, Figure 1.

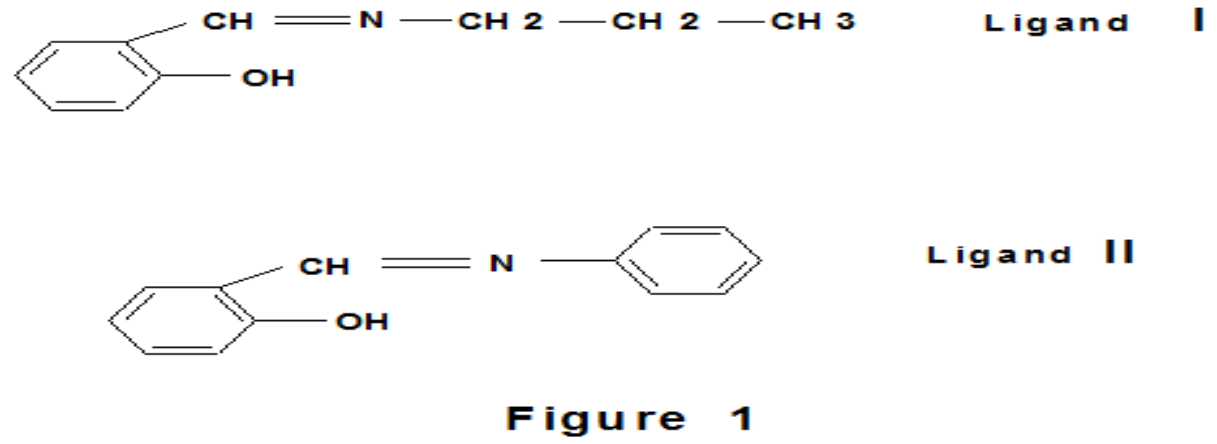

\section{Synthesis Complexes (III ) ${ }^{(13)}$}

A mixture of ligand $\mathbf{I} 6.5 \mathrm{~g}(0.04 \mathrm{~mol})$, and metal chlorides $2.7 \mathrm{~g}(0.02 \mathrm{~mol})$ in $100 \mathrm{ml}$ ethanol. The mixture of reaction was refluxed on a water- bath for $10 \mathrm{~h}$. The solution obtained was left at room temperature. The precipitate was filtered, washed with ethanol and recrystallized from ethanol - chloroform $(1: 3, \mathrm{v} / \mathrm{v})$. dried over anhydrous $\mathrm{CaCl}_{2}$, dark black solid, $86 \%$ yield , m.p >300. Characterized by elemental analysis and IR, UV spectra. The structure was showed in the Figure 2
Synthesis Complex ( IV ) ${ }^{(14)}$

$5.9 \mathrm{~g}(0.03 \mathrm{~mol})$ ligand ( II ) , and $2 \mathrm{~g}$ ( $0.015 \mathrm{~mol})$ metal chloride were mixed with $100 \mathrm{ml}$ ethanol and heated under refluxed for $2 \mathrm{~h}$. On cooling a crude product was formed, filtration and washed with mixture ethanol water

( $3: 1, \mathrm{v} / \mathrm{v})$. dried over anhydrous $\mathrm{CaCl}_{2}$, brown solid, $84 \%$ yield, m.p. $>300$. Characterized by elemental analysis and IR, UV spectra. The structures are showed in the Figure2.

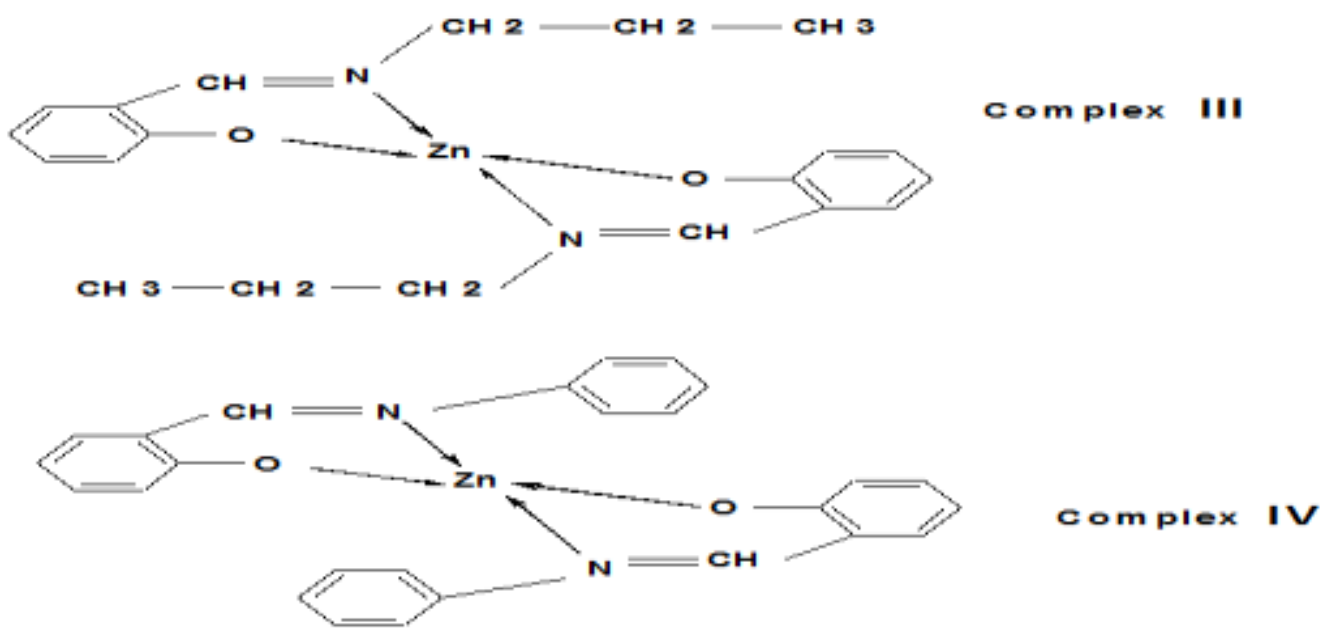




\section{Study of Electronic Properties}

\section{Computational Methods}

Electronic structure methods provide useful information on the molecular structure and charge distribution, so they are useful to understand and describe systems where electronic effects and molecular orbital interactions are dominant. Depending on the theoretical assumptions used for calculations, electronic structural methods belong to one of two fundamental groups: $a b$ initio and semi-empirical ${ }^{(15)}$. Semi-empirical methods use parameters derived from experimental values that simplify theoretical calculations. These methods usually do not require long computation times, and lead to qualitative descriptions of molecular systems. In particular, the semi-empirical PM3 method makes uses of an accurate procedure to predict chemical properties, through a simplified Hartree-Fock (HF) Hamiltonian ${ }^{(16,17)}$. Based on the above considerations, the following methodology was chosen for our computer simulations. A full quantum mechanical geometry optimization with no symmetry restrictions was performed at the semi-empirical PM3 level of theory.

Two Schiff base ligands and their $\mathrm{Zn}$ complexes were optimized by the semiempirical PM3 method. All calculations were performed on the Pentium (R)4/IPMPC- CPU $3.00 \mathrm{GHz}, 2.00 \mathrm{~GB}$ of RAM.

\section{Result and Discussion}

In this paper, we describe the synthesis of $\mathrm{Zn}$ (II)-Complexes(III,IV), were formed in good yield, the ligands and its complexes are stable at room temperature and are nonhygroscopic. The elemental analysis data suggest that the complexes have ratio 1:2 ( metal - ligand ) stoichiomtry. Based on the elemental chemical analysis has been suggested, for complexes(III,IV) the formula $\mathrm{ML}_{2}$. The analytical and physical data for the ligands and their complexes are listed in Table 1.

\section{UV Spectra ${ }^{(18,19)}$}

The electronic absorption spectra of the Schiff-base ligands(I, II) and its complexes(III, IV) were recorded at room temperature using DMF as solvent. The essential absorption of prepared compounds were appeared red shift ( Bathochromic ) comparing with free ligand. The absorption band at $285 \mathrm{~nm}, 305 \mathrm{~nm}$ respectively is observed in the spectrum of the free Schiffbases(I, II), suggesting the presence of $(\pi$ $\left.\pi^{*}\right)$ transition. For Zn- complexes(III,IV), the spectral data display two bands at $350,410 \mathrm{~nm}$ and $330,370 \mathrm{~nm}$ respectively. The first band is due to $\left(\pi-\pi^{*}\right)$ transition, which can be assigned to electron delocalization over whole molecule on complexation, the second band is attributed to (d-d)transitions due to transfer of electrons from nitrogen - oxygen to the empty d-orbitals of the metal atom( donors and acceptor). The all bands were show in Figures( 6,7,8,9).

Table (1).

\section{IR Spectra $^{(20,21)}$}

The Schiff-base and their complexes were identified by IR spectroscopy in the range $(4000-600) \mathrm{cm}^{-1}$ as $\mathrm{KBr}$ discs are shown in Figures 10,11,12,13. The $\mathrm{OH}$ group in ligand(I,II) was appeared in the range $3010-3405 \mathrm{~cm}^{-1}$ and $3110-3480$ $\mathrm{cm}^{-1}$ respectively, while it disappeared in the IR-spectra of the Schiff-base complexes(III,IV) which may be attributed to deprotonation and formation of the metal ion M-O. The absorption bands at 1645, $1625 \mathrm{~cm}^{-1}$ in Zn-complexes(III, IV) 
respectively are due to $v(\mathrm{C}=\mathrm{N})$ vibrations ligands 1610- $1625 \mathrm{~cm}^{-1}$, this fact can be taken as an evidence of the coordination of azomethine nitrogen and oxygen to metal atom, and this can be explained by the donation of electrons from nitrogen oxygen to the empty d-orbitals of the metal atom . The $(\mathrm{C}-\mathrm{H})$ stretching bands in ligand (I ,II) appear in the region $2885-2960 \mathrm{~cm}^{-}$ 1 and 3010-3095 $\mathrm{cm}^{-1}$ respectively, while in complexes(III, IV) appear in the region $2811-2925 \mathrm{~cm}^{-1}$ and $3050 \mathrm{~cm}^{-1}$ respectively. while corresponding bands in the free The $(\mathrm{C}-\mathrm{H})$ bending bands(out of plane) in ligand (I ,II) appear in the region 620 and $620 \mathrm{~cm}^{-1}$ respectively, while in complexes(III, IV) appear in the region 710$700 \mathrm{~cm}^{-1}$ respectively. The new of bands in $\mathrm{Zn-complexes(III,} \mathrm{IV)} \mathrm{at} \mathrm{the} \mathrm{range} \mathrm{735-720}$ $\mathrm{cm}^{-1}$ and at the range 624-611 $\mathrm{cm}^{-1}$ respectively, have tentatively been assigned to $v \mathrm{M}-\mathrm{O}$ and $v \mathrm{M}-\mathrm{N}$ respectively. The all mentioned bands were shown in Table (2)

Table- 1- Analytical and physical data of the ligand (I,II) and their complexes (III,V).

\begin{tabular}{|c|c|c|c|c|c|c|c|}
\hline Compound & Color & $\begin{array}{c}\text { M.P or dec. } \\
\text { temp }{ }^{0} \mathbf{C}\end{array}$ & $\begin{array}{c}\text { U.V/Visible. } \\
\lambda \text { max. } \\
\text { nm }\end{array}$ & $\begin{array}{c}\text { Yield } \\
(\%)\end{array}$ & \multicolumn{3}{|c|}{$\begin{array}{c}\text { Calculated } \\
\text { (Found)(\%) }\end{array}$} \\
\cline { 5 - 8 } & & & & $\mathbf{C}$ & $\mathbf{H}$ & $\mathbf{N}$ \\
\hline $\begin{array}{c}\text { Ligand } \\
\text { I }\end{array}$ & yellow & $102-103$ & 285 & 91 & 73.59 & 8.02 & 8.57 \\
$(7.96)$ & $(8.22)$ \\
\hline $\begin{array}{c}\text { Ligand } \\
\text { II }\end{array}$ & Red & $53-54$ & 305 & 89 & $\begin{array}{c}79.17 \\
(78,76)\end{array}$ & $\begin{array}{c}5.61 \\
(5.43)\end{array}$ & $\begin{array}{c}7.09 \\
(7.11)\end{array}$ \\
\hline $\begin{array}{c}\text { Zn-Complex } \\
\text { III }\end{array}$ & $\begin{array}{c}\text { Dark } \\
\text { black }\end{array}$ & $>300$ & $350-410$ & 86 & $\begin{array}{c}61.62 \\
(60.54)\end{array}$ & $\begin{array}{c}6.20 \\
(6.19)\end{array}$ & $\begin{array}{c}7.18 \\
(7.11)\end{array}$ \\
\hline $\begin{array}{c}\text { Zn-Complex } \\
\text { IV }\end{array}$ & Brown & $>300$ & $330-370$ & 84 & $\begin{array}{c}68.20 \\
(68.13)\end{array}$ & $\begin{array}{c}(4.40 \\
(4.25)\end{array}$ & $\begin{array}{c}6.11 \\
(5.04)\end{array}$ \\
\hline
\end{tabular}

Br:broad, s:sharp, m:medium, w:weak 


\section{Table - 2- IR data for prepared compounds}

\begin{tabular}{|c|c|c|c|c|c|c|c|c|}
\hline \multirow{2}{*}{ Compounds } & \multicolumn{8}{|c|}{ Wave numbers $\left(\mathrm{cm}^{-1}\right)$} \\
\hline & $\begin{array}{c}\text { v } \\
\text { O-H } \\
\text { br }\end{array}$ & $\begin{array}{c}v \\
\text { C-H } \\
\text { stretch ing } \\
\text { m }\end{array}$ & $\begin{array}{c}\mathbf{v} \mathbf{N}=\mathbf{C} \\
\mathbf{s}\end{array}$ & $\underset{\mathbf{m}}{\mathbf{v}} \mathbf{C}=\mathbf{C}$ & $\begin{array}{c}\mathbf{v} \\
\mathbf{C - O} \\
\mathbf{m}\end{array}$ & $\begin{array}{c}\mathbf{v} \\
\mathbf{C - H} \\
\text { bending } \\
\mathbf{w} \\
\end{array}$ & $\begin{array}{c}\mathbf{M}-\mathbf{N} \\
\mathbf{w}\end{array}$ & $\begin{array}{c}\text { vo } \\
\mathbf{M}-\mathbf{O} \\
\mathbf{w}\end{array}$ \\
\hline Ligand I & $\begin{array}{c}3010-3405 \\
\text { br }\end{array}$ & $\begin{array}{c}2885-2960 \\
\mathrm{~m}\end{array}$ & $\begin{array}{c}1625 \\
\mathrm{~s} \\
\end{array}$ & $\begin{array}{c}1478 \\
\mathrm{~m}\end{array}$ & $\begin{array}{c}1125 \\
\mathrm{~m}\end{array}$ & 620 & -- & -- \\
\hline Ligand II & $\begin{array}{c}3110-3480 \\
\text { br }\end{array}$ & $\begin{array}{c}3010-3095 \\
\mathrm{~m}\end{array}$ & $\begin{array}{c}1610 \\
s\end{array}$ & $\begin{array}{c}1485 \\
\mathrm{~m}\end{array}$ & $\begin{array}{c}1120 \\
\mathrm{~m}\end{array}$ & 620 & -- & -- \\
\hline Zn-Complex III & -- & $\begin{array}{c}2811-2925 \\
\mathrm{~m}\end{array}$ & $\begin{array}{c}1645 \\
\mathrm{~s}\end{array}$ & $\begin{array}{c}1470 \\
\mathrm{~m}\end{array}$ & $\begin{array}{c}1138 \\
\mathrm{~m}\end{array}$ & 710 & $\begin{array}{c}624 \\
\mathrm{~m}\end{array}$ & $\begin{array}{c}735 \\
\mathbf{m}\end{array}$ \\
\hline $\begin{array}{l}\text { Zn-Complex } \\
\text { IV }\end{array}$ & -- & $\begin{array}{c}3050 \\
\mathrm{~m}\end{array}$ & $\begin{array}{c}1625 \\
\mathrm{~s}\end{array}$ & $\begin{array}{c}1480 \\
\mathrm{~m}\end{array}$ & $\begin{array}{c}1130 \\
\mathrm{~m}\end{array}$ & 700 & $\begin{array}{c}611 \\
\mathrm{~m}\end{array}$ & $\begin{array}{c}720 \\
\mathrm{~m}\end{array}$ \\
\hline
\end{tabular}

\section{HyperChem Calculation}

To calculate the properties of a molecule, we need to generate a welldefined structure, a calculation often requires a structure that presents a minimum on a potential energy. HyperChem contains several geometry optimizers to do this. We are calculate properties of a molecule and use the optimized structure as a starting point for subsequent calculations. Such as total energy $(\mathrm{ev})$, dipole moment, heat of formation $(\mathrm{kcal} / \mathrm{mol})$, electronic energy $(\mathrm{ev}), \quad$ core-core repulsion(ev), symmetry.bond distance $\left(\mathrm{A}^{0}\right)$ and bond angles ${ }^{(22,23)}$. The optimized structures to Two Schiff base ligands( I, II ) and their Zn-complexes (III,IV) are visualized in (Figs 3 ,I , II, III, V sequence) and selected parameters of their structural data are summarized in
Table3.In both complexes (III,IV), the ligands can coordinate to the $\mathrm{Zn}$ (II) through the phenol oxygen and azomethine nitrogen. In complex $\mathrm{Zn}(\mathrm{L} 2)_{2}(\mathrm{IV})$ the distance between $[\mathrm{d}(\mathrm{N}-$ $\mathrm{Zn})=1.92 \mathrm{~A}^{0}$ ] and the distance between $\left[\mathrm{d}(\mathrm{O}-\mathrm{Zn})=1.85 \mathrm{~A}^{0}\right]$ are shorter than in complex $\mathrm{Zn}(\mathrm{L} 1) 2(\mathrm{III})-\quad[\mathrm{d}(\mathrm{N}-\mathrm{Zn}) \quad=2.01$ $\left.\mathrm{A}^{0}\right], \quad\left[\mathrm{d}(\mathrm{O}-\mathrm{Zn}) \quad=1.97 \quad \mathrm{~A}^{0}\right]$ due to presence of $\pi$-conjugation in the coordinated anion with aromatic ring (phenyl) in ligand (L2)(II) and shorter than the average values in corresponding structures because of electrostatic attraction between both oxygen and nitrogen and zinc

cation $^{(24)}$. On the other hand, the $\pi$ conjugation causes the decrease of Schiff base bond length in complex $\mathrm{Zn}\left(\mathrm{L}_{2}\right)_{2}$ (IV) $\left[\mathrm{d}(\mathrm{C}-\mathrm{N})=1.27 \quad \mathrm{~A}^{0}\right]$, compared with the 
complex $\mathrm{Zn}\left(\mathrm{L}_{1}\right)_{2}$ (III) $\left[\mathrm{d}(\mathrm{C}-\mathrm{N})=1.31 \mathrm{~A}^{0}\right.$, this behavior reflects the strong electrostatic

distance between $\left[\mathrm{d}(\mathrm{C}-\mathrm{O})=1.36 \mathrm{~A}^{0}\right]$ are shorter than in complex $\mathrm{Zn}(\mathrm{L} 1) 2$ (III) the distance between $\left[\mathrm{d}(\mathrm{C}-\mathrm{O})=1.30 \mathrm{~A}^{0}\right]$ while the distance between $\left[\mathrm{d}(\mathrm{C}-\mathrm{O})=1.36 \mathrm{~A}^{0}\right]$ in ligands are equilibrium The computed heat of formation, total energy, electronic energy, core-core repulsion energy, ionization potential and their other computed results (for compounds I-IV) on the basis of PM3 method are given in the Table 3. Variation of total energy for compounds I-IV is shown in the Table.4. The computed total energy values for Schiff base complexes ( III, IV ) are less than Schiff base ligand (I,II) which attraction between the amino group and the zinc cation ${ }^{(25)}$. In complex $\mathrm{Zn}(\mathrm{L} 2)_{2}$ (IV) the indicates the stability of Schiff base complexes (III, IV) ${ }^{(26)}$. The dipole moment plays a key role in establishing the active site of the ligand, for complex formation and hence these values are also given in the Table (4) for Schiff bases . The dipole moment for the compounds (I - IV) (Table 4) shows that this parameter has the appreciable high values for complexes compared with its Schiff base ligand, which also supports the fact that these Schiff bases prove to be effective ligands for the purpose of complex formation ${ }^{(27,28)}$.

Table 3: Molecular descriptors of observed compounds.

\begin{tabular}{|c|c|c|c|c|}
\hline \multirow[t]{2}{*}{ PARAMETERS } & \multicolumn{4}{|c|}{ OMPOUNDS } \\
\hline & L1 (l) & L2 (II) & $\mathrm{Zn}(\mathrm{L} 1)_{2}(\mathrm{III})$ & $\mathrm{Zn}(\mathrm{L} 2)_{2} \quad(\mathrm{IV})$ \\
\hline Heat of formation (KCAL $/ \mathrm{mol})$ & -26.73 & 13.61 & 3.17 & 181.17 \\
\hline Total Energy (eV) & -1841.32 & -2164.83 & -3678.27 & -4321.06 \\
\hline Electronic Energy (eV) & -2034.74 & -2290.44 & -29782.29 & -38806.06 \\
\hline Core - Core Repulsion (eV) & 193.41 & 125.61 & 26104.02 & 34485.00 \\
\hline Dipole (debye) & 3.79 & 3.81 & 6.14 & 7.97 \\
\hline Symmetry & $\mathrm{C} 1$ & $\mathrm{Cs}$ & $\mathrm{C} 2$ & $\mathrm{C} 1$ \\
\hline Gradient Norm & 258.18 & 324.89 & 1199.82 & 1875.58 \\
\hline No. of Fields Level & 32.00 & 37.00 & 64.00 & 74.00 \\
\hline Ionization Potential (eV) & 9.33 & 9.13 & 8.20 & 7.33 \\
\hline Homo & -9.33 & -9.13 & -8.20 & -7.33 \\
\hline Lumo & -0.60 & -1.03 & -0.59 & -1.64 \\
\hline Molecular Weight & 163.21 & 197.23 & 389.80 & 457.83 \\
\hline Scf Calculations & 76.00 & 134.00 & 485.00 & 969.00 \\
\hline
\end{tabular}



J.Thi-Qar Sci.
Vol.2 (4)
Feb./2011
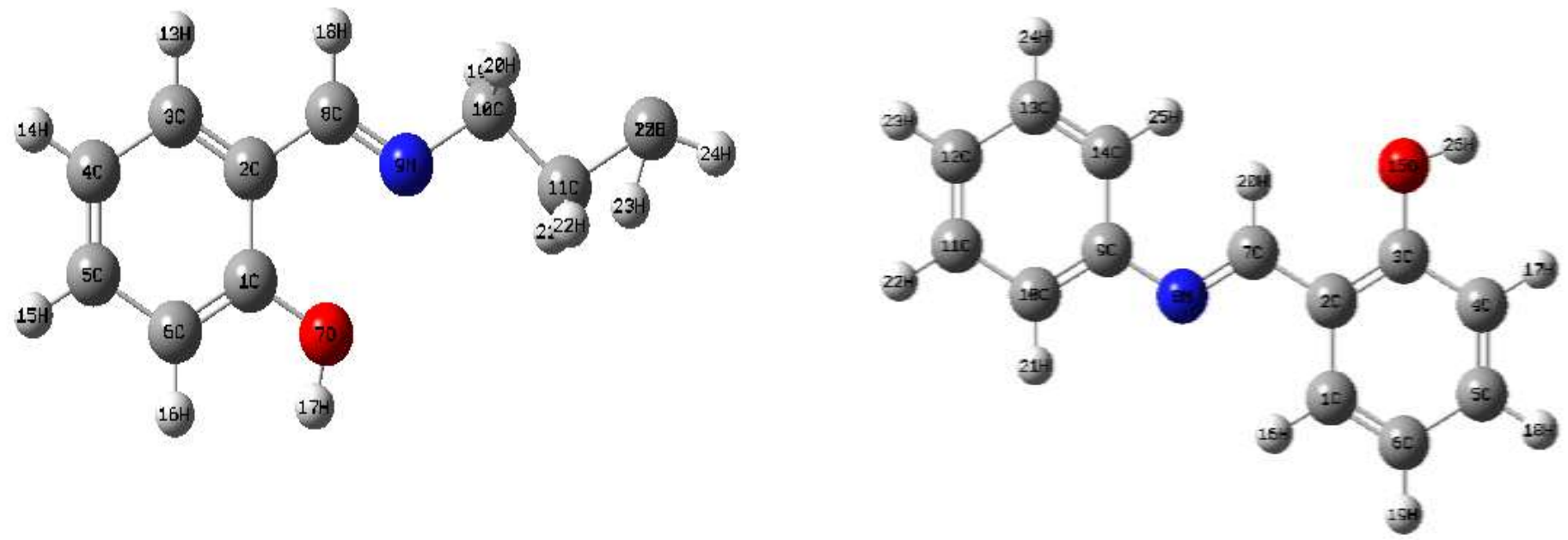

$\mathbf{L}_{1}$ ( I )

$\mathrm{L}_{2}$ ( II )
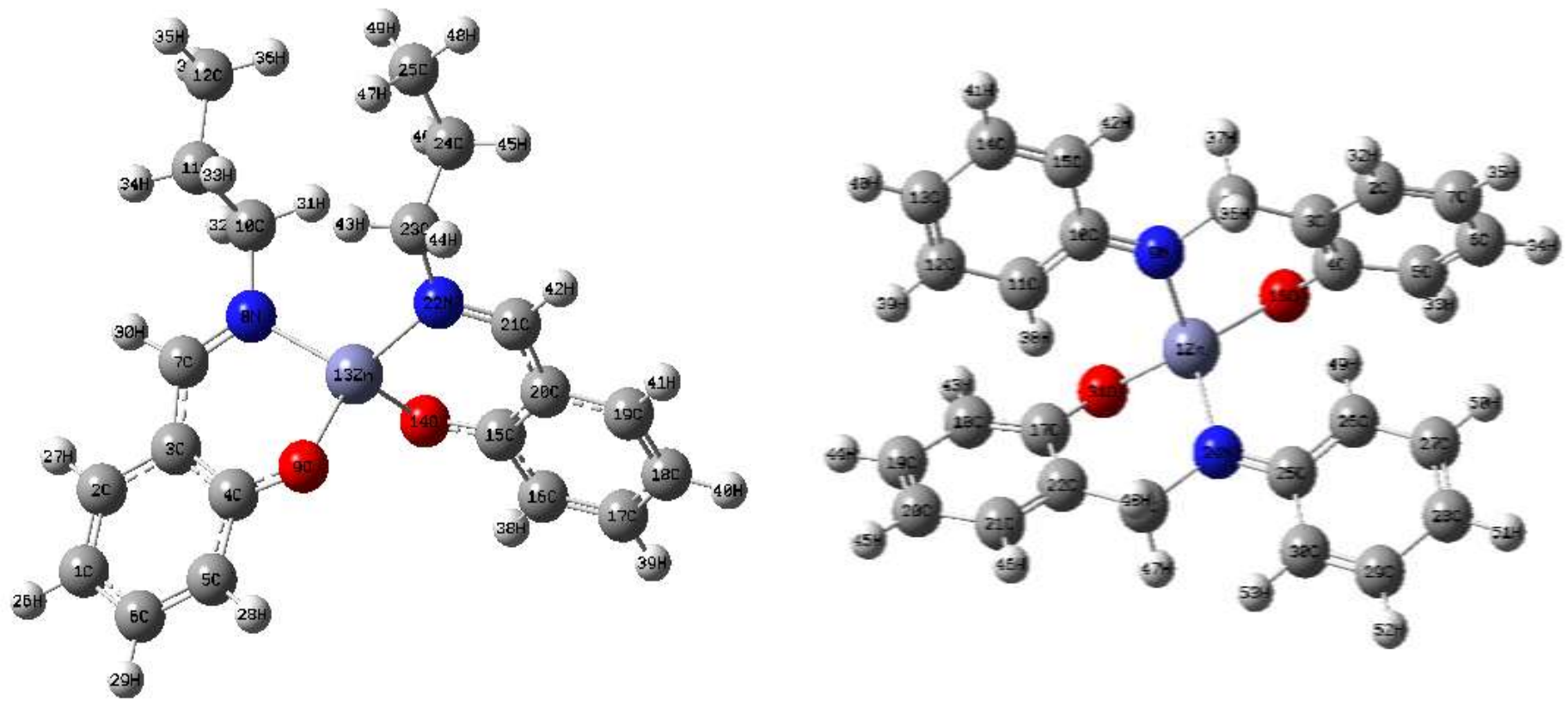

Zn-(L) $)_{2}$ ( III )

Zn-( L $)_{2}(I V)$

Figure 3: PM3 geometry of the compounds 
Table 4: Selected structural parameters of the optimized compounds, bond distance $\left(\mathrm{A}^{\circ}\right)$ and bond angles in $\left(^{\circ}\right)$ as obtained from PM3 method

\begin{tabular}{|c|c|c|c|c|}
\hline \multirow{2}{*}{$\begin{array}{l}\text { BONDSI } \\
\text { ANGLES }\end{array}$} & \multicolumn{4}{|c|}{ COMPOUNDS } \\
\hline & LI (I) & L2 ( II) & $\operatorname{Zn}($ L1) 2 ( III) & $\operatorname{Zn}(L 2)_{2}($ IV) \\
\hline$C_{6}-C_{7}$ & 1.46 & 1.46 & 1.43 & 1.35 \\
\hline $\mathrm{C}_{7}-\mathrm{N}$ & 1.29 & 1.3 & 1.31 & 1.27 \\
\hline $\mathrm{C}_{5}-\mathrm{O}$ & 1.36 & 1.36 & 1.30 & 1.36 \\
\hline $\mathrm{N}-\mathrm{C}_{10}$ & 1.46 & 1.43 & 1.48 & 1.27 \\
\hline$C_{10}-C_{11}$ & 1.52 & 1.40 & 1.53 & 1.35 \\
\hline $\mathrm{O}-\mathrm{H}$ & 0.97 & 0.97 & - & - \\
\hline $\mathrm{C}_{7}-\mathrm{H}$ & 1.10 & 1.10 & 1.10 & 1.10 \\
\hline$C_{5}-C_{6}$ & 1.41 & 1.41 & 1.42 & 1.35 \\
\hline$C_{1}-C_{6}$ & 1.40 & 1.40 & 1.42 & 1.35 \\
\hline $\mathbf{N}-\mathbf{Z n}$ & - & - & 2.01 & 1.92 \\
\hline O-Zn & - & - & 1.97 & 1.85 \\
\hline$C_{6}-C_{5}-O$ & 123.46 & 123.43 & 127.77 & 124.73 \\
\hline $\mathrm{C}_{6}-\mathrm{C}_{7}-\mathrm{H}$ & 117.71 & 118.80 & 115.66 & 113.97 \\
\hline $\mathrm{C}_{6}-\mathrm{C}_{7}-\mathrm{N}$ & 118.63 & 118.92 & 125.98 & 132.15 \\
\hline $\mathrm{C}_{7}-\mathrm{N}-\mathrm{C}_{10}$ & 122.06 & 121.83 & 120.26 & 124.22 \\
\hline $\mathrm{N}-\mathrm{C}_{7}-\mathrm{H}$ & 123.64 & 122.27 & 118.34 & 113.83 \\
\hline $\mathrm{C}_{5}-\mathrm{O}-\mathrm{H}$ & 107.48 & 107.75 & - & - \\
\hline $\mathrm{C}_{5}-\mathrm{O}-\mathrm{Zn}$ & - & - & 119.95 & 114.28 \\
\hline O-Zn-O & - & - & 118.76 & 112.47 \\
\hline O-Zn-N & - & - & 114.07 & 111.38 \\
\hline $\mathbf{N}-\mathbf{Z n - N}$ & - & - & 112.12 & 115.76 \\
\hline
\end{tabular}

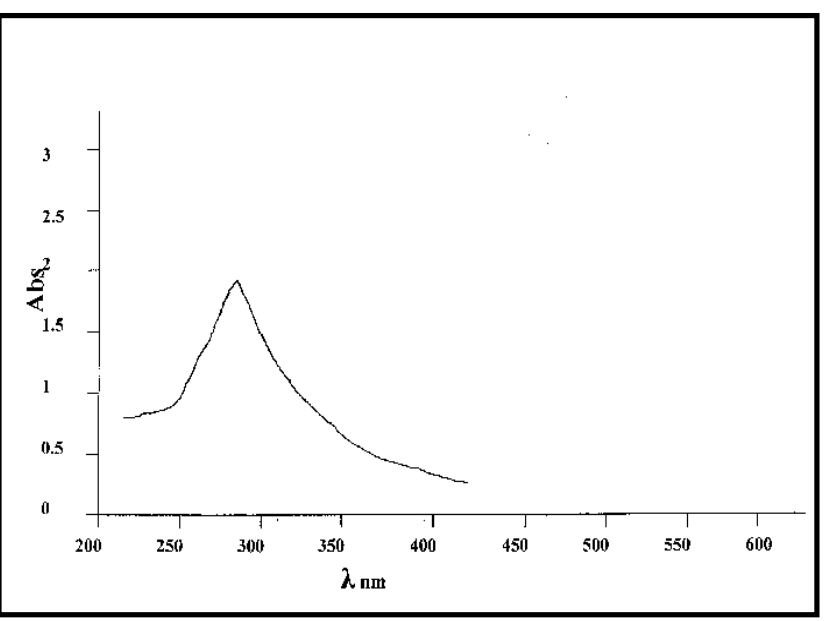

Figure 6: UV-Visible spectra of ligand ( I ) in DMF $\left(1 \times 10^{-5}\right) \mathrm{M}$

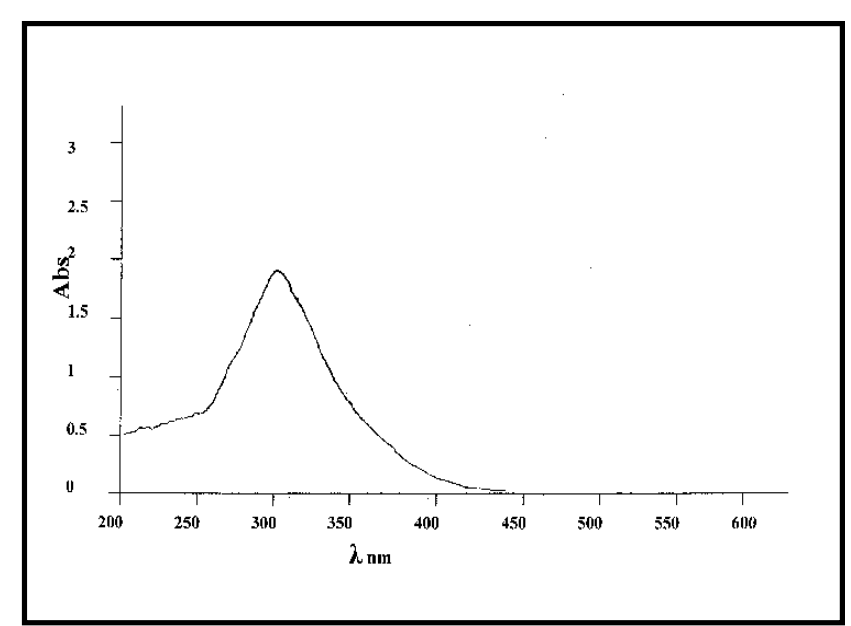

Figure 7: UV-Visible spectra of ligand ( II ) in $\operatorname{DMF}\left(1 \times 10^{-5}\right) \mathrm{M}$ 


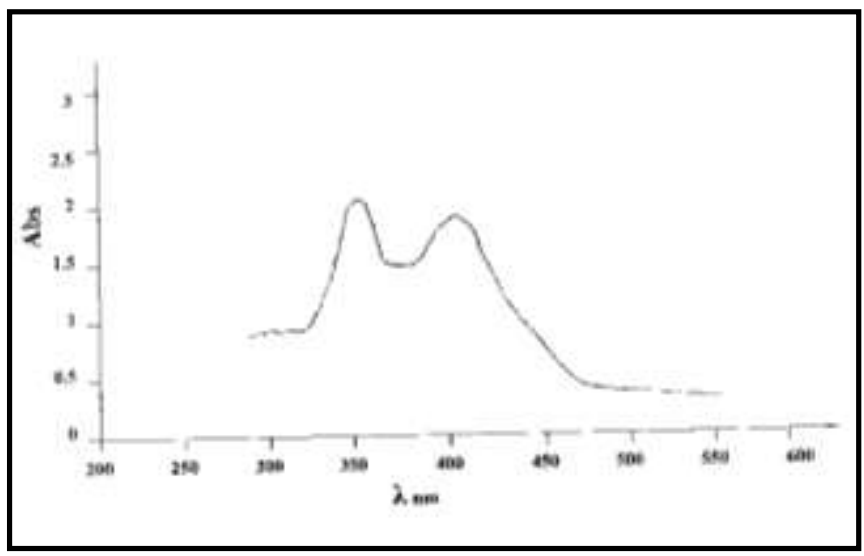

Figure 8: UV-Visiblespectra of Zn-complex (III) in DMF $\left(1 \times 10^{-5}\right)$

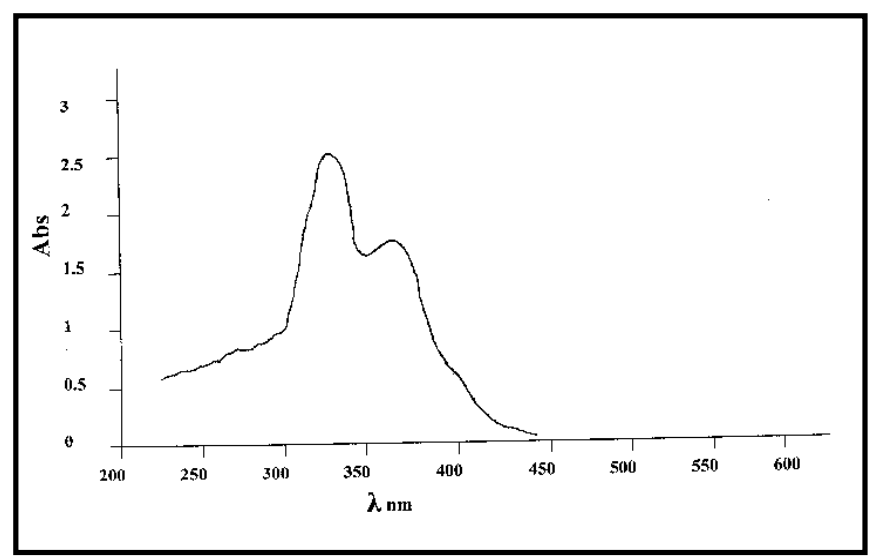

Figure 9: UV-Visible spectra of $\mathrm{Zn}$-comlex (IV) $\mathrm{M}$ in $\operatorname{DMF}\left(1 \times 10^{-5}\right) \mathrm{M}$

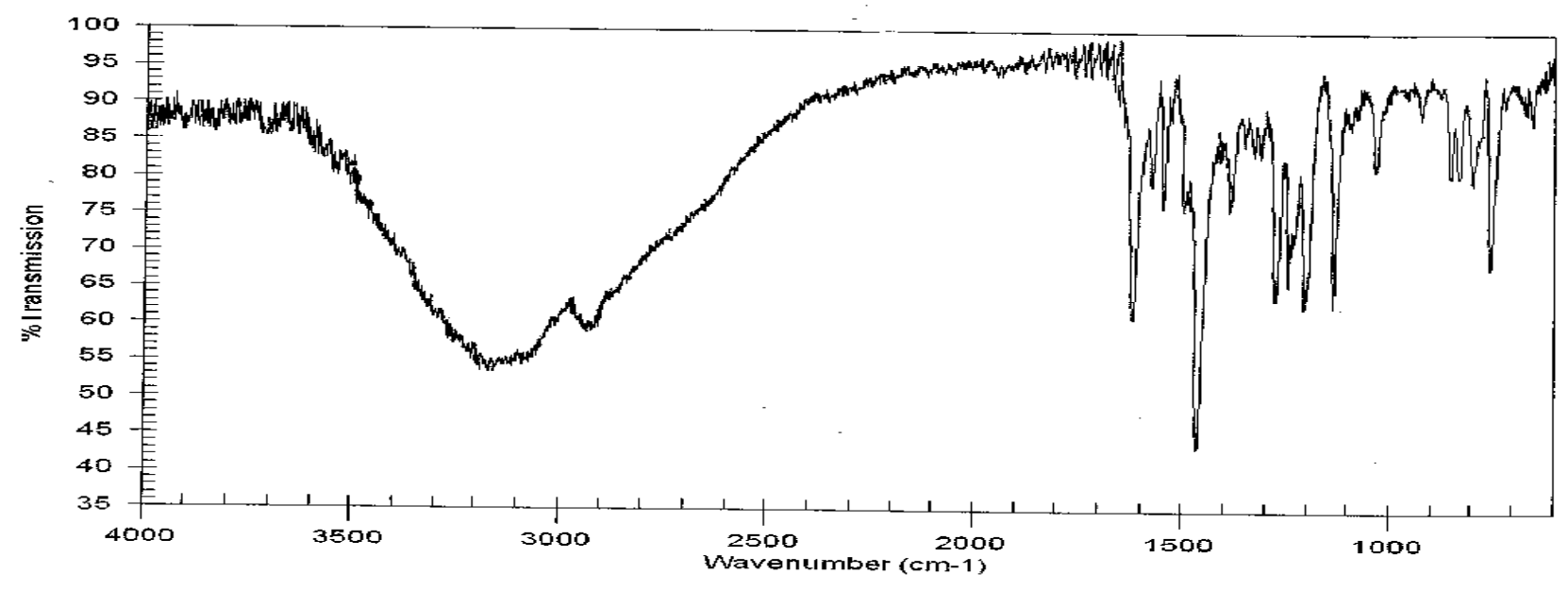

Figure 10: IR-spectrum of Ligand I. 


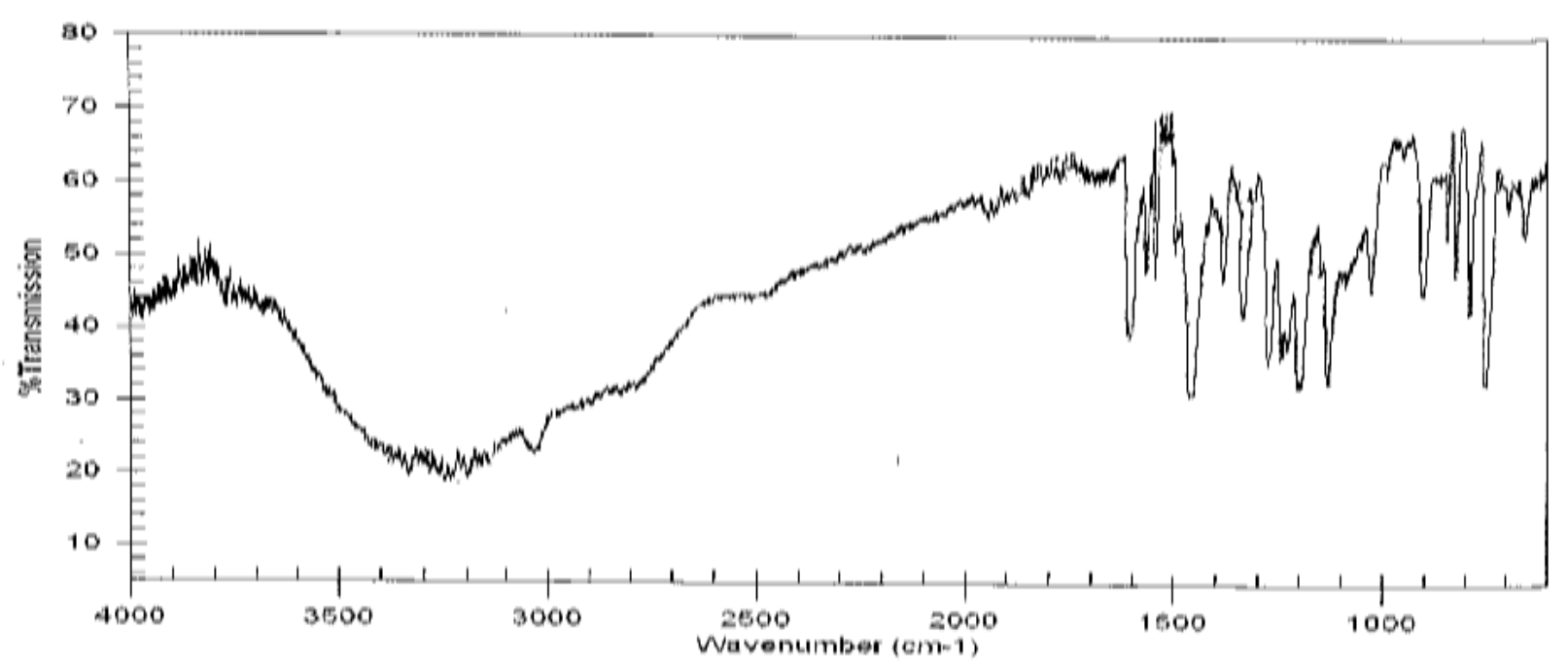

Figure 11: IR-spectrum of Ligand II

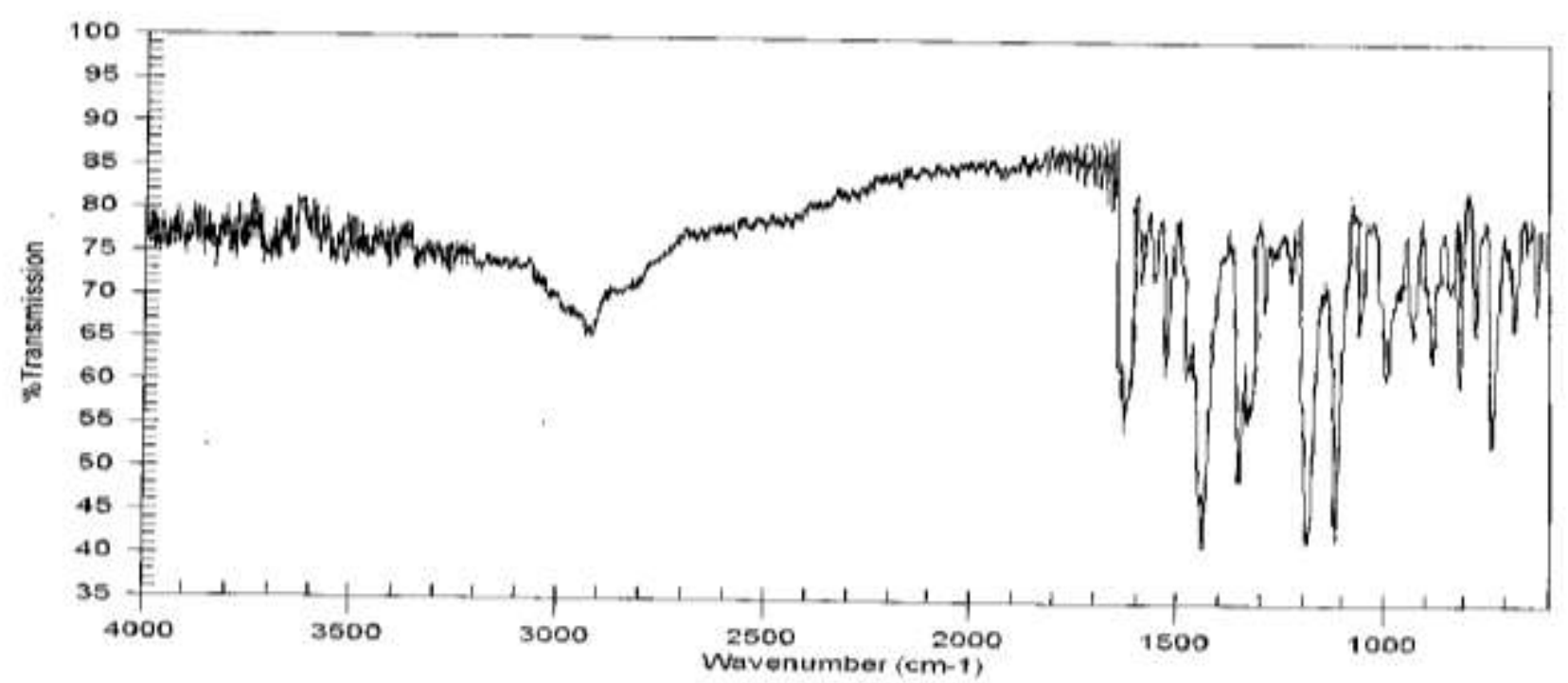

Figure 12: IR-spectrum of Zn-complex III 


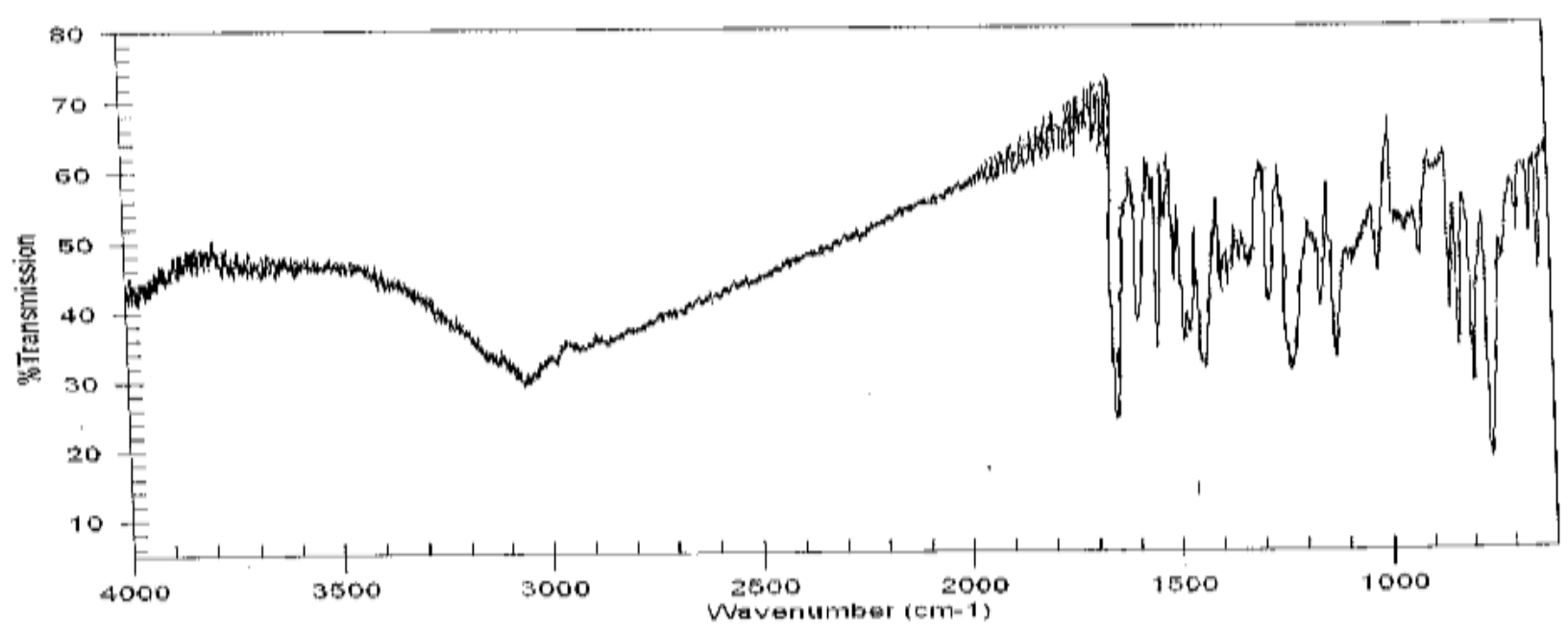

Figure 13: IR-spectrum of Zn-complex IV

\section{Conclusions:}

In complex $\mathrm{Zn}\left(\mathrm{L}_{2}\right)_{2}$ (IV) the distance $\mathrm{N}$ $\mathrm{Zn}$ and distance $\mathrm{O}-\mathrm{Zn}$ are shorter than in complex $\mathrm{Zn}\left(\mathrm{L}_{1}\right)_{2}$ ( III) because of $\pi$ conjugation with aromatic ring (phenyl) in ligand $\left(\mathrm{L}_{2}\right)(\mathrm{II})$ and shorter than the average values in corresponding structures because of electrostatic attraction between both oxygen and nitrogen and zinc cation. This behavior reflects the strong electrostatic attraction between the amino group and the zinc cation. Total energy for Complex (III, IV) less than Schiff base ligands ( I, II), strongly indicates the stability of complexes ( III, IV ) . Dipole moment have maximum values for complexes compared with their Schiff base lgiands. This high dipole moment may make the complexes attractive for the interaction with other systems

\section{Reference:}

1. K. Arora and K.P. Sharma, (2003); Synth. React. Inorg. Met.-Org. Chem. 32, 913.

2. P.A. Vigato and S. Tamburini, Coord. (2004); Chem. Rev. 248, 1717

3.T. Katsuki, Coord. (1995); Chem. Rev. 140, 189

4.T.D. Thangadurai, M. Gower and K. Natarajan, (2002); Synth. React. Inorg. Met.-Org.Chem.32,329.

5.R. Ramesh and M. Sivagamasundari, (2003) ; Synth. React. Inorg. Met.-Org. Chem. 33, 899

6.Stewart, J.J.P., (1995); J. Computational Chem., 10, 209.

7. Hehre W. J., Radom L., Schleyer P. V. R., Pople J. (1986) ; A. Ab Initio Molecular Orbital Theory; Wiley:New York.

8.M.J.L. Dewer, E.G. Zoebisch, E.H. Healy and J.J. D. Stewart, ( 2006); J. Am. Chem. Soc., 177, 3994 
9.Ed. K. B. Lipkowitz and D. B. Boyd, (2006); "Reviews in Computational Chemistry 10.G.W.Atkins and B. Elich. (2008);"Molecular Modelling Principles and Applications" 44,925

11.Raff. L. and P. Lopez, (2008); J. Am. Chem. Soc. 132, 14725-14727.

12.W. L . F . Armarego and D. D . Perrin, (1998); "Purification of Laboratory Chemicals" . 101, 208

13.M. Kaya and P.Nair, S. Baluja , (2007); J. Serb. Chem., Soc, 72, 1265.

14. A. M. Appeal., M. R. Dubois., , (2008); Inorg. Chem., 45, 3056.

15. J. Yamada, Y. Inomata, T. Tahechi, (1996); Inorg. Chem. Acta, 249, 121.

16.Hehre, W.J. , (2003); A Guide to Molecular Mechanices and Quantum Chemical Calculations; Wavefunction Inc.; Irvine, CA.

17.L. W. Eojan, S, Geralden, (2006), J. Mol. Struct. THEO-CHEM.,772, 425.

18.Denney, R. C.; Sinclair, R. , (1987); Visible and Ultraviolet Spectroscopy, John Wiley \& Sons: London, p53.

19.C. Thangaraji and A. R. Afzal,(2007); Indian J. Chem., 43, 1176.
Volume 6".Ed. K.H. Lipkowitz and D. B. Boyd, VCH.

20.W. J.Crriddle and G.P.Eilis, "Spactral and Chemical Charactreization of organic Compounds". ThirD Edition Great Britauin (1994).

21.E. Canpolat, M. U. Zakiva, (2008), Russian J. Coord. Chem. 33, 123.

22. Rico, J. F., Lopez, R., Ema, I., Ramirez, G. , (2005); J. Chem. Theory Comput. 1, 1083-1095.

23. R. Ludwig, S. Metivier, (2004);J. Anal. Chem. 378, 126.

24. F.Brito, A.Mederos, L. Martin. (2005); Inorg. Chim. Acta, 288, 411.

25. V. M. Amirkhanov, V. A. Ovchinnikov, V. A. Trush, V. V. Skopenko, (1996); Zh.Organ. Khimii(Russ) 32, 376.

26. G. S. Girolami, N. Reddig, C. Slinn, (2006); Eur. J. Inorg. Chem.893.

27.J.Smith, S. Tanaka, (2004); J. Phys. Chem. A112:8224.

28. J. Van, T. M. Korter, and D. W. Pratt. (2007); J. Am. Chem. Soc. 128,11396. 